УДК 376.42

\title{
ФОРМИРОВАНИЕ ГУМАНИСТИЧЕСКОГО МИРОВОЗЗРЕНИЯ У УЧАЩИХСЯ С ИНТЕЛЛЕКТУАЛЬНЫМИ НАРУШЕНИЯМИ \\ НА УРОКАХ ЧТЕНИЯ И РАЗВИТИЯ РЕЧИ НА МАТЕРИАЛЕ ТВОРЧЕСТВА Г.А. СКРЕБИЦКОГО В 5-6 КЛАССАХ
}

Завалина Юлия Олеговна ФГБОУ ВО «Вятский государственный университет»

Аннотация. Проблема формирования гуманистического мировоззрения учащихся с интеллектуальными нарушениями в современном мире стоит наиболее остро. Формирование гуманистического мировоззрения у учащихся с интеллектуальными нарушениями имеет ряд трудностей, связанных со структурой данного дефекта. Целенаправленное формирование гуманистического мировоззрения у учащихся с интеллектуальными нарушениями необходимо для их дальнейшей успешной социализации.

Ключевые слова: интеллектуальные нарушения, развитие речи, обучение, воспитание, мировоззрение, гуманизм.

\section{CREATION OF A HUMANISTIC WORLDVIEW AMONG STUDENTS WITH INTELLECTUAL DISABILITIES IN READING AND SPEECH DEVELOPMENT LESSONS BASED ON THE MATERIAL OF G.A. SKREBITSKY 5TH - 6TH GRADE}

\section{Zavalina Yulia Olegovna master "Vyatka State University"}

\begin{abstract}
It is difficult to create a humanistic worldview in children with mental retardation. Their special educational needs make this difficult. It is necessary to work specially to create a humanistic worldview in such children.
\end{abstract}

Keywords: mental retardation, speech development, training, education, worldview, humanism.

Проблема формирования гуманистического мировоззрения учащихся с интеллектуальными нарушениями в современном мире стоит наиболее остро. 
Жизнь без мировоззрения, по мнению Альберта Швейцера, представляет собой патологическое нарушение высшего чувства ориентирования. [1, с. 82].

Формирование гуманистического мировоззрения у учащихся $\mathrm{c}$ интеллектуальными нарушениями имеет ряд трудностей. Ещё в период дошкольного возраста у учащихся с интеллектуальными нарушениями не формируются предпосылки для развития нравственных представлений о добре и зле. В младшем школьном возрасте развитие когнитивного, эмоционального и поведенческого компонентов нравственных представлений у учащихся с интеллектуальными нарушениями имеет качественное своеобразие. Целенаправленная работа по формированию гуманистического мировоззрения у учащихся с интеллектуальными нарушениями должна продолжаться и в старших классах, в связи с отставанием в психическом развитии данной категории учащихся.

Органическое поражение мозга приводит к волевому недоразвитию учащихся с интеллектуальными нарушениями. По причине неумения управлять своими действиями, их слабой мотивированности, а также вследствие специфических проблем с целеполаганием, учащиеся с интеллектуальными нарушениями легко подвержены любому влиянию, в том числе и негативному, что затрудняет формирование гуманистического мировоззрения у данной категории учащихся. Некритичность мышления, импульсивность, склонность к перепадам поведения от упрямства до вялости и апатичности, недостаточная дифференцированность чувств, примитивность переживаний свидетельствуют о незрелости духовно-нравственных потребностей у учащихся с интеллектуальными нарушениями. Все вышеперечисленное свидетельствует о необходимости целенаправленной работы по формированию гуманистического мировоззрения у учащихся с интеллектуальными нарушениями.

Формирование гуманистического мировоззрение у учащихся с интеллектуальными нарушениями возможно через изучение раздела программы «Картины родной природы» в 5-6 классах на материале творчества Г.А. Скребицкого по произведениям «Добро пожаловать», «Сентябрь», «Всяк по-своему», «Декабрь», «Март» (5 кл.); «Весенняя песня» (6 кл.).

На материале творчества Г.А. Скребицкого в 5-6 классах на уроках чтения и развития речи можно сформировать следующие элементы гуманистического мировоззрения:

- Нравственные чувства, эмоции, такие как любовь к родине, родному краю; 
- Знания, полученные с опорой на жизненный опыт: знания о животных, растениях, о природе родного края;

Убеждения: патриотические убеждения, экологические убеждения (необходимость бережного отношения к природе);

- Гуманистические ценности: патриотизм, сохранность природы, национальная история и культура.

Целенаправленное формирование гуманистического мировоззрения на уроках русского языка и чтения, отражённые в деятельности учащихся 5 - 6 кл. с интеллектуальными нарушениями приводит к следующим результатам: умение определять тему и проблему произведений; умение составлять план текста (сжатый, подробный), вопросы к тексту; развитие речи (связной, монологической, диалогической); формирование базовых учебных действий (личностных), представленных следующими умениями: бережное отношение к культурно-историческому наследию родного края и страны, чувство любви к родине.

С целью формирования гуманистического мировоззрения на материале произведения Г.А. Скребицкого «Добро пожаловать», 5 кл. применяются следующие методы и приёмы:

- Словарная работа («манок», «сторожка», «рябчиное утро», «березняк», «ельник», «лесовик», «логовище»);

- Смысловое чтение. Чтение отрывков из текста, ответы на вопросы по содержанию текста. Размышления о содержании текста («О чём думал дед Семён, увидев поваленную бурей сосну? Какие это были мысли? Грустные или весёлые? Почему вы так думаете?» и т.д.;

- Чтение и пересказ отрывка («Как медведь устраивает себе берлогу?»);

- Изучение иллюстраций к тексту. Придумывание заголовка к иллюстрации;

- Составление плана текста, придумывание заголовка к частям текста. Пересказ рассказа по плану;

- Ответы на вопросы по тексту, позволяющие определить тему и проблему текста («Для кого поваленная сосна оказалась нужной и полезной? Как иллюстрация помогает понять название рассказа «Добро пожаловать»? Кому люди говорят «добро пожаловать»?).

С целью формирования гуманистического мировоззрения на материале произведения Г.А. Скребицкого «Сентябрь», 5 кл. применяются следующие методы и приёмы: 
- Словарная работа («соня», «погребки», «логовища», «день осеннего равноденствия»);

- Работа с текстом. Особенности текста (повторы, однородные члены);

- Работа с пониманием текста: «Когда наступает день осеннего равноденствия? Что это значит?»;

- Закрепление знаний об осенней природе с опорой на жизненный опыт («Что можно наблюдать в природе осенью? Какие изменения в жизни животных, птиц и насекомых происходят осенью? Все ли перелётные птицы улетают в одно время? Почему? Опиши осень в своём городе»);

- Работа с содержанием текста («Как звери, птицы и насекомые готовятся к зиме? Найди ответ в тексте. Назови все приметы осени, описанные в тексте»)

С целью формирования гуманистического мировоззрения на материале произведения Г.А. Скребицкого «Всяк по-своему», 5 кл. применяются следующие методы и приёмы:

- Словарная работа («петли», «тетерев», «ястреб»);

- Смысловое чтение. Чтение отрывков из текста, ответы на вопросы по содержанию текста. Поиск ответа в тексте и на иллюстрации: «Чему научился зайчишка у лосей, тетеревов? Ответ найдите в тексте и на иллюстрации»;

- Составление вопросов к содержанию отрывка из текста. Написание ответов на составленные вопросы;

- Анализ особенностей произведения («Чем эта история похожа на сказку»?);

- Пересказ от лица героя произведения (рассказ сказки от лица зайца).

С целью формирования гуманистического мировоззрения на материале произведения Г.А. Скребицкого «Декабрь», 5 кл. применяются следующие методы и приёмы:

- Словарная работа («петли», «тетерев», «ястреб», «индюк», «озимые хлеба»). Объяснение лексических значений слов «хлеба», «хлебы»;

- Работа со структурными особенностями текста. Поиск «слов-связок», указывающие на смену времени года, однородных членов;

- Вопросы по содержанию текста («Какие изменения произошли в природе с наступлением зимы? Как проводят зиму животные, растения, птицы?);

- Работа над пониманием текста («Каким днём является 21 декабря? Что он значит?»);

- Подбор словаря к пунктам плана. Составление подробного плана текста, передающего его содержание 
С целью формирования гуманистического мировоззрения на материале произведения Г.А. Скребицкого «Март», 5 кл. применяются следующие методы и приёмы:

- Словарная работа («водосточные трубы», «горизонт», «кучевые облака», «косогоры», «день весеннего равноденствия»;

- Работа со структурными особенностями текста: поиск слов, обозначающих действия, c помощью которых автор хочет показать переменчивость весенней погоды, красоту пробуждения природы от зимней спячки; обилие однородных членов;

- Вопросы по содержанию текста. («Как радуются весне птицы? Как меняется погода? Найдите в тексте первые приметы весны. Какая пора наступает в природе? Прочитайте и расскажите, почему её так называют);

- Закрепление знаний о весенней природе с опорой на жизненный опыт («Расскажите, какие изменения в природе вы наблюдали ранней весной?);

- Анализ понимания текста («Каким днём является 21 марта? Что это значит»).

С целью формирования гуманистического мировоззрения на материале произведения Г.А. Скребицкого «Весенняя песня», 6 кл. применяются следующие методы и приёмы:

- Словарная работа («пурга», «пёстрый», «трескотня», «овсянки», «славки», «малиновки». Почему слова «Весна» и «Зима» в сказке написаны с большой буквы?;

- Определение темы текста («О каком времени года говорится в сказке? Как вы это поняли?»);

- Анализ структурных особенностей текста. Поиск образных слов и выражений, служащих для описания весенних лесов и лугов;

- Работа над содержанием текста («Кто из птиц пытается помочь Весне? Почему птицы не смогли прогнать Зиму? Помочь Весне? Найди ответ в тексте. Чья песня прогнала Зиму?»);

- Подробный рассказ с опорой на текст («Прочитайте и расскажите подробно о том, как жаворонок спел первую весеннюю песенку»);

- Выразительное чтение текста по ролям («Прочитайте по ролям разговор Весны с Зимой и птицами»).

Формирование гуманистического мировоззрения играет важную роль в социализации учащихся с интеллектуальными нарушениями [2, С. 32]. Формирование гуманистического мировоззрения поможет избежать поиска 
нежелательных средств компенсации, влияющего на появление вредных привычек; способствует развитию первоначально слабых убеждений и стремлений. Опора на жизненный опыт позволит усвоить абстрактные нравственные категории, которые послужат ориентиром учащемуся с интеллектуальными нарушениями, зачастую неспособному оценить последствия своих поступков и действий с точки зрения причинноследственных связей. Усвоение нравственных ценностей, моральных норм, убеждений, закрепление знаний на основе индивидуального опыта является важным результатом изучения предмета «Чтение и развитие речи»;

На уроках «Чтения и развития речи» мы можем формировать различные элементы гуманистического мировоззрения, такие как нравственные чувства, эмоции, знания, ценности, убеждения у учащихся с интеллектуальными нарушениями на материале творчества Г.А. Скребицкого в 5-6 классах. Формирование гуманистического мировоззрения развивает нравственное осознание учащихся и приводит к усвоению ими культурно-нравственных норм поведения в обществе.

\section{Список литературы}

1. Швейцер, А. Благоговение перед жизнью / А. Швейцер. - М.: Прогресс, 1992. -572 c.

2. Ермолаев Д.О. Социализация детей с интеллектуальными недостатками развития // Фундаментальные исследования. - 2013. - № 9-1. - С. 32 - 36. 